\title{
The European Charter of Fundamental Rights A Changed Political Opportunity Structure and its Dogmatic Consequences
}

Christoph Engel

January 2001

Max-Planck-Projektgruppe Recht der Gemeinschaftsgüter, Poppelsdorfer Alle 45, 53115 Bonn

www.mpp-rdg.mpg.de 


\section{The European Charter of Fundamental Rights}

A Changed Political Opportunity Structure and its Dogmatic Consequences

I. THE ISSUE 2

II. A CHANGED POLITICAL OPPORTUNITY STRUCTURE 3

A. Introduction 3

B. Changed Conditions for European Policy Making 4

1. European Union and Member States 4

2. Member States to each other 5

3. Organs of the European Union 6

$\begin{array}{lll}\text { 4. Political actors } & 7\end{array}$

C. $\quad$ Fundamental Rights When Democratic Legitimation is Weak $\quad 8$

D. Fundamental Rights for a System of Multilevel Governance 9

E. Consequences for the State Character of the European Union $\quad 9$

III. DOGMATIC CONSEQUENCES 11

A. Dogmatics of the European Fundamental Rights $\quad 11$

$\begin{array}{ll}\text { 1. Addressees and attackable acts } & 11\end{array}$

$\begin{array}{lr}\text { 2. Interference } & 12\end{array}$

$\begin{array}{ll}\text { 3. Formal limitations } & 13\end{array}$

4. Material limitations $\quad 13$

$\begin{array}{ll}\text { 5. Duties to protect } & 15\end{array}$

B. Relation of European Fundamental Rights and Remaining Primary Law 17

C. Relation to Other Fundamental Rights Codes $\quad 17$

IV. OPEN FLANKS 19

* This paper partly relies on a German Study on the Impact of the European Charter of Fundamental Rights on the Press (Zeitschrift für Urheber- und Medienrecht 2000, 975. I am grateful to the Stiftung für Demokratie und Pressefreiheit and the Stiftung Freiheit der Presse, that ordered the study, to use the material in this context.

I also am indebted to Adrienne Héritier and Marco Verweij for helpful comments, and to Joachim Dölken for research assistance. 


\section{The Issue}

Good constitutions are short and enigmatic. This eases the agreement on the wording. Nobody really knows in what he is about to engage. The fathers of the constitution draw an artificial curtain of ignorance in front of the already existing dense curtain of the future ${ }^{1}$. The Treaties of Rome, on whom the European Economic Community was originally based, even went one step further. The travaux préparatoires have, deliberately, never been disclosed. On the contrary, the Treaty placed the interpretation in the hands of a powerful international court, the European Court of Justice.

History has proven the fathers of the Treaties of Rome to have been correct. The challenges that nature or foreign countries can pose to a community is as unforeseeable as the politic processes and the development of mentalities within the countries. Furthermore constitutions are necessarily compromises between different, even fundamentally incompatible viewpoints, from which the world can be understood and valued ${ }^{2}$. It is sound when a constitution does not try to provide determination on these views. Instead, it should search for instruments that allow for a continual redrawing of the various pictures of social reality that are drawn from these different views.

The European Union is preparing to add a Fundamental Rights Charter to its Constitution ${ }^{3}$. The draft obeys the fundamentals laid out above ${ }^{4}$. The text neither lays the dogmatics of the new freedoms out nor addresses it their impact on policy making in Europe. Yet the Charter of Fundamental Rights has the potential to fundamentally change the opportunity structure for European politics (II). These impacts have to be kept in mind when developing the dogmatics of the new freedoms (III). Open flanks remain that might call for further legislative action (IV).

1 This metaphor has its own history. See first J.Rawls, A Theory of Justice (Harvard, 1971) 136-142 and passim; afterwards G.Brennan/J. M. Buchanan, Die Begründung von Regeln. Konstitutionelle Politische Ökonomie (Die Einheit der Gesellschaftswissenschaften 83) (Tübingen, 1993) 37, 184 f., 196 and passim.

2 Stimulating: M. Thompson/R. Ellis/A. Wildavsky, Cultural Theory (Boulder, 1990); G. Calabresi, Ideals, Beliefs, Attitudes and the Law. Private Law Perspectives on a Public Law Problem (Syracuse, 1985).

3 Out of the preparatory documents see in particular: for freedom rights Council Document Charte 4123/1/00 REV 1 of 15.02 .2000 ; 4149/00 of 08.03 .2000 ; 4137/00 of 24.02.2000; for the democratic rights see document 4170/00 of 20.03.2000; for the economic and social rights see document 4192/00 of 27.03.2000 and document $4193 / 00$ of 29.03 .2000 .

Details for background and history of development: Eickmeier 'Eine europäische Charta der Grundrechte. Bericht über das gemeinsame Forum des Bundesministeriums der Justiz und der Vertretung der Europäischen Kommission in Deutschland' (1999) Deutsches Verwaltungsblatt 1026; Schwarze, 'Auf dem Wege zu einer Europäischen Verfassung. Wechselwirkungen zwischen europäischem und nationalem Verfassungsrecht (1999) Deutsches Verwaltungsblatt 1677; Däubler-Gmelin 'Eine Europäische Charter der Grundrechte - Beitrag zur gemeinsamen Identität' (2000) Europäische Zeitschrift für Wirtschaftsrecht 1; Weber, 'Die Europäische Grundrechts-Charter - auf dem Weg zu einer Europäischen Verfassung' 2000 (Neue Juristische Wochenschrift) 537; B. Steppacher, EU-Grundrechtscharta. Ziele - Methoden - Bewertung (St.Augustin, 2000); Stock, 'Eine Grundrechtscharta für die Europäische Union. Wie sollte die Medienfreiheit darin ausgestaltet werden ?’ (2000) Zeitschrift für Urheber- und Medienrecht 533; Sporn, 'Das Grundrecht der Meinungs- und Informationsfreiheit in einer Europäischen Grundrechtscharta' (2000) Zeitschrift für Urheber- und Medienrecht 537; V. Miller, Human Rights in the EU. The Charter of Fundamental Rights (House of Commons Research Paper 00/32) 2000 .

4 Council Document Charte 4487/00 of September 28 has the wording. See also Document Charte 4955/00 of October 17, expressing the informal approval by the Heads of State. 


\section{A Changed Political Opportunity Structure}

\section{A. Introduction}

The European Council has limited the assignment of the preparatory body, the Convention, in the sense, that a catalogue of fundamental rights should be drafted that is neither part of the EC or the EU-Treaty nor subject to an independent international organ for its application ${ }^{5}$. If it remained this way, the Charter of Fundamental Rights would not be more than an expression of good will. A differentiation by Robert Alexy makes this particularly clear: he refers to the fact that most of the fundamental rights are in fact principles and not rules. The underlying structure of fundamental freedoms is finality; not conditionality. Fundamental rights do not make 'if-then-statements' but impose aims on their addressees ${ }^{6}$. Without a procedure for their authentic application fundamental rights are therefore - at least from a legal point of view ${ }^{7}$ - cheap talk.

The initiators of the European Charter of Fundamental Rights have therefore from the very beginning intended more ${ }^{8}$. Even if the Community initially only decides for a declaration, the initiators could still be successful in the end, be that on legal or on political grounds. The European Court of Justice has drawn fundamental rights from the unwritten primary law of the Community? The Court of Justice could hold that the Charter of Fundamental Rights codifies these unwritten fundamental rights of Community law. Political hope is put on the expectation that the Community overcomes the opposition of Member States by means of the long practised 'salami' tactic $^{10}$. First it coaxes approval of the principle from the Member States. After a while it draws concrete political conclusions and in doing this refers to the fact that the principle is beyond dispute ${ }^{11}$. In the following it is thus assumed that the Charter of Fundamental Rights finally became a justifiable element of the primary law of the Community.

Litigable fundamental rights have an enormous impact on the political opportunity structure of the Community. The term should be understood as it stands. The opportunities for impacting on the political process within the Community change; whether the political actors seize the new opportunities, depends on many more factors, and especially on the prevalent (legal) culture ${ }^{12}$. Likewise, the fact that the Charter would give the European Court of Justice new opportunities for legal activism does not necessarily imply that the Court will actually use them. Cultural factors like the subsidiarity debate might counsel it to act with prudence.

5 In the decision of the European Council of Cologne this is dressed in the glossed-over formula: "The European Council will advise the European Parliament and the Commission to solemnly proclamate together with the Council a Charter of Fundamental Rights of the European Union on the basis of this draft. Afterwards there will have to be investigation as to if and how the Charter can be incorportated in the Treaties".

R. Alexy, Theorie der Grundrechte (Frankfurt $\left.{ }^{3}, 1996\right)$ p.17-158.

Political scientists are right in emphasising that symbolic policy can also have impacts. It may alter cognitive models or opinions, overcomes taboos and prepares the next political step.

Däubler-Gmelin (note 3) EuZW 2000, 1.

In summary: H.-W. Rengeling, Grundrechtsschutz in der europäischen Gemeinschaft. Bestandsaufnahme und Analyse der Rechtsprechung des Europäischen Gerichtshofes zum Schutz der Grundrechte als allgemeine Rechtsgrundsätze (München, 1993) p.179-198.

In more detail: A. Héritier, Policy-Making and Diversity in Europe. Escaping Deadlock (Cambridge, 1999) p.17.

Ibid $53 \mathrm{f}$. for the Großfeuerungsanlagenverordnung, and 77 for the social policy.

Prominent on this Kagan ,Should Europe Worry About Adversarial Legalism ?‘ (1997) Oxford Journal of Legal Studies 165 . 
The structure of the institutions in the Community is altered, both in relation to its Member States and within the Member States (B). The effect differs from the catalogues of fundamental rights of national constitutions because the behaviour of the Community is much less democratically legitimised (C). Because of the principle of 'restricted vested powers', European policy occurs on a system of different levels. The European fundamental rights only include a part of this system (D). They have the potential to alter the state character of the European Union (E).

\section{B. Changed Conditions for European Policy Making}

From a functional point of view, a justiciable catalogue of fundamental rights alters the constitution of the Community ${ }^{13}$. By means of the altered institutional framework the conditions under which policy is made between the Community and the Member States (1), among the Member States themselves (2), among the organs of the Community (3) and in relation to outside political actors (4) shift.

\section{European Union and Member States}

The constitutional political discussion about a European Charter of Fundamental Rights is governed by the concern of an extension of the competencies of the Community. To meet this concern Article 51 II shall contain the following sentence:

"The Charter does not establish any new power or task for the Community or the Union, or modify powers and tasks defined by the Treaties ${ }^{\text {(114 }}$.

From a judicial point of view this clarification would not even be necessary. The principle of the 'restricted vested powers' would not be touched by the establishment of a catalogue of fundamental rights in the EC or EU-Treaty. Furthermore, Article 6 II EC obliges the Community to respect the fundamental freedoms of Community citizens in any event ${ }^{15}$.

Nevertheless, the Charter for Fundamental Rights will inevitably have a unitarian effect ${ }^{16}$. The experience with the German Constitution can prove this. By means of the ever increasing density of the constitutional standards the legislative competencies of the German Länder, which are formally

13 By this I do not mean to take sides on a dispute dividing German public lawyers: is it wise to extend the term constitution to an entity that nobody intends to be a state ?, see in detail the proceedings [*** Veröffentlichungen der Vereinigung der Deutschen Staatsrechtslehrer 2000, forthcoming ***].

For a comparative view on the impact of a constitutional court, interpreting fundamental rights, on the political opportunity structure see Shapiro 'The European Court of Justice: Of Institutions and Democracy' (1998) Israel Law Review 3.

14 For earlier versions see Art. H.1 II Doc. 4235/00 and the preamble or Art. 1, S 3 of the draft in Doc. 4123/1/00 REV 1.

15 Schwarze (note 3) DVBl. 1999, 1685 has been right in pointing to both of them.

16 Miller (note 3) House of Commons RP 00/32, 19, citing Power, ,Human Rights and the EEC', in L. Hefferman (ed.), Human Rights. A European Perspective, 1994; cf. also Dorau/ Jacobi, ,The Debate over a ,European Constitution'. Is it Solely a German Concern ?" (2000) 6 European Public Law, 413, p.426: „Although this Charter - in the official wording - has nothing to do with a constitution, it will inevitable prepare the ground for one“. 
not touched, are hollowed out more and more. The most obvious example is the one of broadcasting. The jurisdiction of the Bundesverfassungsgericht regarding Article 5 I 2 Basic Law has not left a lot of the original competence of the Länder to regulate broadcasting ${ }^{17}$.

The political effects of the Charter of Fundamental Rights are less obvious. They create a new political window of opportunity ${ }^{18}$, not only for the Community, but also for the Member States, enterprises and citizens. The consequences for the state character of the European Union will further attract our attention later on ${ }^{19}$. A greater political weight for the Community can result from this. When the Court of Justice uses the fundamental rights offensively, it gains an additional instrument to overcome political blockades, like it has done in the past, relying on the fundamental freedoms as guaranteed by the EC-Treaty. According to the way in which the initiative right is arranged, the Commission could raise an action before the Court of Justice against a decision of the Council and the Parliament, on the grounds of violation of the fundamental rights of the Community. This would enable the Commission to shift political conflicts with the Member States to a forum in which it expects better chances of success.

The right of initiative would surely not be reserved to the Commission though, but at least as well to the Member States. It would be logical to also admit complaints by enterprises and citizens ${ }^{20}$. Otherwise there would actually not be any European Fundamental Rights but - in terms of public international law - merely a European regime of diplomatic protection ${ }^{21}$. The individual itself would have no standing, but would be in need of protective institutions. From a political point of view it is important how the right of initiative is distributed, because it gives its holders the opportunity, with the help of the Court of Justice, to dictate a different agenda to the Community. As long as the Court of Justice participates, papering over conflicts and symbolic politics could be unmasked at an early stage ${ }^{22}$. The political organs of the Community will anticipate such claims. Even without the actual intervention of the Court of Justice their behaviour can thus be expected to change.

\section{Member States to each other}

Justiciable fundamental rights also alter the relation between the Member States because the substantiate threat to attack an act of the Community legislature by means of the European Fundamental Rights gives additional negotiating power to a Member State. By these means it can triumph during negotiations in the Council. It can also influence the Commission beforehand to foil a draft for a regulation or directive that conflicts with its interests. This threat is especially suitable for two constellations. Both constellations can be thoroughly examined in the example of environmental law.

In the first constellation environmental law differs between the Member States regarding the level of protection. Some states have strong regulations, others more generous ones. Since a better

17 K. Gabriel-Bräutigam, Rundfunkkompetenz und Rundfunkfreiheit. Eine Untersuchung über das Verhältnis der Rundfunkhoheit der Länder zu den Gesetzgebungszuständigkeiten des Bundes (Law and Economics of International Telecommunications 12) (Baden-Baden, 1990).

18 To this: Héritier Deadlock (note 10) 11 with more material.

19 See below E.

20 For the considerations during the preparation of the German initiative for a European Charter of Fundamental Rights see: Eickmeier (note 3) DVBl. 1999, 1029; see also Rengeling, 'Brauchen wir die Verfassungsbeschwerde auf Gemeinschaftsebene?' Festschrift Everling II (Baden-Baden, 1995) 1187.

21 Comprehensively: Geck, ,Diplomatic Protection', in Encyclopedia of Public International Law I, 1046.

22 Compare Héritier Deadlock (note 10) 17 and $18 \mathrm{f}$. 
protection of the environment is usually more expensive, the states with high regulations are keen on imposing these rules to other Member States by harmonisation of the European law. For a long time the German environmental policy has been successful with this strategy ${ }^{23}$. However, distortion of competition is also possible when the Member States generally agree about the need and level of protection, but traditionally use different instruments for these purposes. If the Community elevates the instrument of one Member State to that of a European standard, it imposes the burden of adaptation and disadvantages of competition to all other Member States. The Federal Republic of Germany has had this experience in the past years. In the European environmental policy English ideas have dominated more and more, e. g. the EMAS or the integrated protection of the environment $\mathrm{t}^{24}$.

Fundamental rights are more suitable in negotiations to prevent a regulation than to force it, though. This is only different if, and when, duties to protect or act derive from the fundamental rights, or when a Member State uses its constitutional power to hinder particular legislative activity to force the Community into legislating on other issues.

\section{Organs of the European Union}

The question which effects a catalogue of fundamental rights has on the politic organs of the Community depends on the distribution of the right of initiative. When fundamental rights are incorporated in the EC- or EU- Treaty it is likely that the Commission, the Parliament and the Council will also be entitled to bring actions before the Court of Justice. Experience suggests that legal action between organs of the Community is not very frequent, though. But there have been exceptions. Parliament has used the Court to advance its cause, e.g. in transport policy ${ }^{25}$. The Commission has also repeatedly used this instrument. If, on the other hand, the right of initiative would be reserved for the holders of the fundamental rights, the effect on the relationship between the political organs of the Community would be more slight. However, in negotiations the Parliament or the Commission could refer to the fact that the draft of a regulation was violating the fundamental rights and that a complaint was, consequently, likely.

But above all, litigable fundamental rights would have consequences for the position of the European Court of Justice and for the Court of First Instance within the structure of institutions of the Community. At a first glance it appears obvious that the European Courts are fortified by these additional competencies. At a closer look things look different, though, because fundamental rights of the Community are directed against the policy of the Community, rather than giving it extra leverage. In the past, the Court of Justice has acted as a motor for integration. It has understood itself less as an organ of the judiciary but rather as a political organ. It has seen its main task in breaking institutional blockades and by these means support the growing together of the Member States to form a uniform Europe ${ }^{26}$.

It suits this way of seeing itself that the Court of Justice has not yet made substantial use of the fundamental rights of the Community. It has never applied the highly differentiated dogmatic of the Strasbourg European Court of Human Rights. One cannot lose the impression that the Court of

23 Details in: A. Héritier/C. Knill/S. Mingers, Ringing the Changes is Europe. Regulatory Competition and the Transformation of the State. Britain, France, Germany (De Gruyter Studies in Organization 74) (Berlin, 1996) p. 175-330.

$24 \quad$ Details ibid 238-326.

25 ECJ Case 13/83 [1985] ECR 1513.

26 See details in: F.W. Scharpf, Regieren in Europa. Effektiv und Demokratisch? (Frankfurt 1999) 47-80. 
Justice sees the fundamental rights as "querrelle allemande" to which it, only because of a feeling of duty, makes a few remarks that are without consequence. Of course things do not have to remain this way. The introduction of fundamental rights in the EC- or EU-Treaty could have a signalling impact to which even the Court of Justice could not elude. Even the principle of subsidiarity which is, dogmatically, of poor content, has had its effect on the Court of Justice impelling it to act more cautiously ${ }^{27}$. Moreover, the Court of First Instance has defined its task more in a constitutional than political way from the very beginning. Nevertheless, such a change of the way of seeing itself is not certain.

Even if the Court of Justice were to decide in this direction, it would have to consider the repercussions of the new tasks on the remaining older tasks. According to the German experiences with constitutional claims, the Court of Justice would be overflowed with so many claims that it would have to introduce an open or hidden procedure of admissibility ${ }^{28}$. Up to now, the Court of Justice could elude from this problem because the Treaty of the European Union sets very high standards of admissibility for individuals to bring nullity suits and actions on the grounds of administrative inactivity. If the Court of Justice now were forced to repeatedly deny legal protection, it would also lose some of its legitimacy. This could also have an impact on other tasks of the Court of Justice and on its reputation in the Community and in relation to the citizens of the Community.

\section{Political actors}

Finally justiciable fundamental rights give new fields of activity to national and European political actors that do not hold office. This is mainly the consequence of the right of complaint on the ground of denial of fundamental rights before the ECJ, because the fundamental rights enable the Court of Justice to act politically by repealing a piece of Community legislation, altering it by means of an interpretation which brings it into conformity with the fundamental rights, or to reconstructing the political agenda of the Community. The Court of Justice has been able to do all this for a long time referring to the primary law of the Community. Up to the present the right of initiative of the Court of Justice has been sharply limited though. There has thus often been the prospect of foiling disliked claims beforehand by means of political pressure. The prospects for this are not very promising once individuals can bring cases claiming interference with their fundamental rights. The right of initiative is practically withdrawn from political control. The political actors could use this circumstance to form an alliance with the Court of Justice against the majority in the Council, the Parliament, the Commission or single Member States. One can also put it this way: the complaint on the ground of fundamental rights transforms the Court of Justice to a political arena, in which power is distributed differently ${ }^{29}$.

\footnotetext{
27 The most obvious proof for that is the restriction of freedom of goods on grounds of the Keck jurisprudence, ECJ Case 267 and 268/91 Keck [1993] ECR 6097.

28 Cf. Miller (note 3) 19.

29 Compare Héritier Deadlock (note 10) $20 \mathrm{f}$.
} 


\section{Fundamental Rights When Democratic Legitimation is Weak}

German observers not only bewail the insufficient protection of fundamental rights but also the weak democratic legitimation of the Communities actions ${ }^{30}$. The Bundesverfassungsgericht has expressed its concern in the Maastricht-decision ${ }^{31}$. By means of the direct election of the European Parliament and the extension of co-decision making of the Council and Parliament the extent of the democratic legitimation may have increased. However, the democratic legitimation of European law making remains mainly indirect, derived from the national Parliaments and the controlling governments.

There is also a political explanation. Since the Maastricht Treaty, the EC programmatically speaks of a citizenship of the Union ${ }^{32}$. Nevertheless to a great extent the citizens only feel to be a member of their particular Member State. There are, at best, only the rudiments of a uniform European solidarity. Even where there is a formal cord of legitimacy to the people of the Member States, the power of legitimation is still weak. The willingness to accept a decision solely because it is according to the will of the majority of all citizens of the Union, is hardly existent ${ }^{33}$.

In a political system like the European Community with such weak democratic legislation, fundamental rights constitute a much sharper instrument than in Germany, for example. There, the Bundesverfassungsgericht takes into account the democratically elected legislature in may ways. It grants it room for discretion and prognosis and above all concedes a lot of freedom to the legislature regarding the definition of purposes for which it intervenes with the fundamental rights of the citizens $^{34}$. In this case, fundamental rights become a fairly blunt instrument. A suitable aim can be found for almost every interference with fundamental rights. There is no reason for such restriction in the dogmatic of the fundamental rights when the legislative can, at best, prove marginally stronger democratic legitimation than the judge ${ }^{35}$. Admittedly, in Europe too, the Council as the political organ has better means than the Court of Justice to raise and to bundle together the normative expectations of the persons involved. However, because of the poor democratic legitimation the legislature of the Community must first and foremost argue the appropriateness of the contents of the regulations, instead of the weighing up of the conflicting forces in a political process. To put it in Fritz. Scharpf's terms: it can only rely on output legitimacy, not on input legitimacy ${ }^{36}$. The Court of Justice can therefore permit itself a dissenting decision much more easily when judging the substantial appropriateness of the contents ${ }^{37}$.

\footnotetext{
30 Characteristic: Lübbe-Wolff: [***Veröffentlichungen der Vereinigung der Deutschen Staatsrechtslehrer 2000, forthcoming***].

31 BVerfGE 89, 155, 186 ss. and passim.

32 The appropriate provisions are now included in Articles 17-22 EC.

33 Scharpf Europa (note 26) $29 \mathrm{f}$. and passim.

34 For many consitutional lawyers this is not enough. See the programmatic habilitation of M. Jestaedt, Grundrechtsentfaltung im Gesetz. Studien zur Interdependenz von Grundrechtsdogmatik und Rechtsgewinnungstheorie (Jus Publicum 50) (Tübingen, 1999).

35 Pauly, Strukturfragen des unionsrechtlichen Grundrechtsschutzes. Zur konstitutionellen Bedeutung von Art. F Abs. 2 EUV' (1998) Europarecht 242, p. 245 f.and 256 f., see further 257 and 259.

36 Scharpf Europa (note 26) 30.

$37 \quad$ Pauly (note 35) EuR 1998, 259.
} 


\section{Fundamental Rights for a System of Multilevel Governance}

The European Union is not a state. This derives primarily from the principle of restricted vested powers. The Treaty of Amsterdam has strengthened this principle anew in Article 5 I EC. The Community competencies are generally not exclusive ${ }^{38}$. Nevertheless, this way the Member States lose their universal authority. An economic metaphor demonstrates the consequences. It sees the state as a supplier of public goods. Because of the competencies of the Community, the Member States lose their monopoly of supply. This leads to vertical competition between the institutions of the Community and the Member States ${ }^{39}$. The political sciences talk now about the prospect that political decisions will be made across multiple arenas ${ }^{40}$.

Fundamental rights have a different impact in such a system of multilevel governance than in a uniform, monopolistic state. We have already seen the fact that political actors could instrumentalize their fundamental rights to transfer political conflicts from one level to the other. But the fundamental rights themselves are weaker in such a system. It is of no help anymore for the citizen, when he can realise his freedom on only one of these levels ${ }^{41}$. The single constitution is replaced by a "network of elements of constitutions"42. Expressed more clearly: not only does the national state lose its monopoly, but also the national fundamental rights. The dogmatic consequences will preoccupy us further.

\section{E. Consequences for the State Character of the European Union}

The European Union is an unfinished political system, whose structures are continually moving ${ }^{43}$. The Charter of Fundamental Rights, its incorporation in the EC- or EU-Treaty and the competence of the European Court of Justice for the authentic interpretation of the fundamental rights will be further steps on the way to a European State. The German initiators ${ }^{44}$ and the European Parliament express this quite freely ${ }^{45}$.

$38 \quad$ This follows from Art. 5 II ECC.

39 Schäfer, 'Globalisierung: Entmonopolisierung des Nationalen?', in: H. Berg (Hrsg.): Globalisierung der Wirtschaft. Ursachen - Formen - Konsequenzen (Schriften des Vereins für Socialpolitik NF 263) (Berlin, 1999) 9, p.10 and passim.

40 Programmatic: A. Héritier/D. Kerwer/C. Knill/D. Lehmkubl/M. Teutsch/A.-C. Douillet: Differential Europe. New Opportunities and Restrictions for Policy-Making in the Member States [***in press ${ }^{* * *}$ ].

41 Walter, 'Die Folgen der Globalisierung für die Europäische Verfassungstradition' (2000) Deutsches Verwaltungsblatt 1, p. 9 s. Even more dramatically at Hesse, cited after Schwarze (note 3) DVBl. 1999, 1681: „Wir leben insoweit von dem Gedankengut einer Welt, die nicht mehr die unsere ist und, wie wir immer deutlicher sehen, in den tiefen Wandlungen des ausgehenden 20. Jahrhunderts ihren Untergang gefunden hat. Über ihre Grundlagen, bislang als gesichert geltende Bestandteile der Staats- und Verfassungslehre, ist die Geschichte hinweggegangen“.

$42 \quad$ Walter (note 41) DVB1. 2000, 7.

43 Laffan, 'From Policy Entrepreneur to Policy Manager. The Challenge Facing the European Commission' (1997) 4 Journal of European Public Policy 422; see further Weber (note 3) NJW 2000, 538: Die Europäische Union ist eine ,sich verdichtende, supranationale Hoheitsgewalt“.

44 Däubler-Gmelin (note 3) EuZW 2000, 1.

45 European Parliament Committee on Constitutional Affairs, Doc. PE 232.397, DT \385929EN.doc, 07.12.1999, R 21 and 42. 
However, fundamental rights will also alter the state character of Europe. In future, the organs of the Community will not be able to uncontrollably define the political agenda. Their ability to make politics under the threshold of perception will decrease ${ }^{46}$. But above all the alterations are of importance in the light of the difference of interests and ideas ${ }^{47}$. Fundamental rights establish new regulative ideas ${ }^{48}$. The dispute before the European Court of Justice about the fundamental rights creates new opportunities for deliberation. Such processes strengthen the impact of regulative ideas and decrease the importance of balancing conflicting interests within the political process of the Community ${ }^{49}$.

Fundamental rights have the potential to transfer political conflicts into legal conflicts. This leads to a parallel judicial discourse of political questions. The partial juridification of European politics is the consequence.

Finally, litigable fundamental rights supply the European Community with additional legitimation. Once more the distinction between input and output legitimation is helpful ${ }^{50}$. Input legitimation derives from what jurists call a closed chain of democratic legitimation. Because of the already mentioned reasons this form of legitimation is available to the European legislature to only a limited extent. Output legitimation on the other hand relies on the fact that the legislature succeeds in convincing the addressees about its problem solving capacity. The European Charter of Fundamental Rights contributes to this in various ways. The control of decisions of the Council, the Parliament and the Commission by means of the fundamental rights makes it more difficult for well organised groups to carry through their interests and thereby achieve a distributional gain at the expense of the majority. Thus the chances rise that the European legislation better serves the European public. Because of this, the capacity of the law of the Community to solve problems rises $^{51}$. In the medium term, European identity may even be strengthened because the citizens of the Union will feel as members of a legal community that is held together by common values ${ }^{52}$. In this case more output legitimation would finally lead to more input legitimation.

Fundamental rights also lead to an increase in legitimation of the Community because they provide the citizens with a right to complain ${ }^{53}$. Finally the procedures before the Court of Justice increase the transparency of the legislation of the Community. This too gives them additional legitimation.

46 Compare Scharpf Europa (note 26) 30.

47 Substantially: Yee, 'The Causal Effects of Ideas on Policies' 50 (1996) International Organization 69.

48 Compare Héritier Deadlock (note 10) 14; compare also an extract fo the discourse of the Minister of foreign affairs Fischer to the European Charter of Fundamental Rights, cited in Schwarze (note 3) 1679: „Wir sollten uns dabei von einem strikten rechtlichen Verständnis freimachen und unter ,Verfassung eher eine Zusammenstellung der Werte und der Grundprinzipien europäischen Zusammenlebens einschließlich des Funktionierens der Europäischen Union als Konstrukt sui generis begreifen“.

49 An extensive analysis of the meaning of the difference for the fundamental rights can be found in Engel, 'Delineating the Proper Scope of Government - A Proper Task for a Constitutional Court?', Journal of Institutional and Theoretical Economics [*** forthcoming ***]

$50 \quad$ Scharpf Europa (note 26) 16-28.

51 Grimm, 'Braucht Europa eine Verfassung?' (1995) Juristenzeitung 581, p.590.

52 Such is the hope of the Committee for Citizens' Freedoms and Rights of the European Parliament, PE 232.272/Fin.,AE \375756EN.doc of 07.12.1999, 2.

53 This idea has been substantially examined by R.Dworkin, Taking Rights Seriously, (Duckworth ${ }^{8}$, 1996). 


\section{Dogmatic consequences}

We now can draw normative consequences from these insights. They are obviously to be found in the interpretation of the new fundamental rights themselves (A), but also in the dogmatic links to other provisions of primary Community law (B) and to other codes of fundamental rights (C).

\section{A. Dogmatics of the European Fundamental Rights}

Once more we have to act prognostically and sketch out the dogmatics of fundamental rights that have not yet been decided on. This is not a too speculative task though. Not only can we refer to the wording of the draft, but also to the decisions of the European Court of Justice regarding fundamental rights and, above all, on the decisions of the Strasbourg Court of Justice of Human Rights. Our task is adapting these blueprints in a suitable way for the control of the law of the Community. Five elements of the dogmatic of fundamental rights are in the greatest need to be properly adapted to the specific conditions of fundamental rights in Europe: the definition of the addressee and the attackable acts (1), the concept of interference (2), the formal (3) and the material limitations (4) and finally the duties to protect derived from fundamental rights (5).

\section{Addressees and attackable acts}

As mentioned Article $51 \mathrm{I}$ of the Charter expressly clarifies that is does not constitute a standard of control for Member States acting autonomously. Crucial for this is not the addressees' definition; thereto belong not only the organs of the Community but also the Member States. It is, rather, decisive which acts of these authorities can be attacked. This must depend on whether the authoritative act can at least partly be ascribed to the European Community. This is possible not only in the field of exclusive, but also in the field of competing competencies of the Community ${ }^{54}$. In particular the application and the enforcement of regulations and decisions of the Community by the Member States belong to this field ${ }^{55}$. This conforms with the previous jurisdiction about fundamental rights by the European Court of Justice ${ }^{56}$. The same is the case when directives are directly applicable after the expiration of the time limit of transposition ${ }^{57}$. This case is not likely to become more than theoretical though because the European Court of Justice has expressly excluded a horizontal direct effect, i.e. an effect between private parties ${ }^{58}$.

In the remaining constellations, it is more difficult because the directive gives the Member States some latitude in how to transpose $\mathrm{it}^{59}$. In solving this, the particularities of fundamental rights in a system of multilevel governance have to be taken into account. If one exclusively tested the national act of transposition against the national system of fundamental rights, a double gap of protection

\footnotetext{
54 European Parliament Committee on Constitutional Affairs, PE 232.397, DT \385229EN.doc, 07.12.1999, R 27.

$55 \quad$ Ibid R 19 f.; Eickmeier (note 3) DVBl. 1999, 1028; Weber (note 3) NJW 2000, 542 f.

56 ECJ Case 5/88 Wachauf [1989) ECR 2609, 2639 s.; ECJ Case C-260/89 ERT [1991] ECR I-2925, 2964.

57 Weber (note 3) NJW 2000, 542.

58 Substantially: M. Gellermann, Beeinflussung des bundesdeutschen Rechts durch Richtlinien der EG, dargestellt am Beispiel des europäischen Umweltschutzes (Schriften zum deutschen und europäischen Umweltrecht 2) (Köln, 1994).

59 Weber (note 3) NJW 2000, 542 refers to this.
} 
would occur. At one point the national legislature could object that it is not substantially responsible for its own decision, rather, it only obeyed the duty of transposition of the law of the Community. But even if national constitutional law would not accept this objection, only the standards of the national fundamental rights would be applied to the directive. They differ from one Member State to the other. The Commission would have an incentive to shift from using the regulation to using the directive, and by these means, make European fundamental rights blunt.

The most elegant solution lies in procedural law. It would allow the citizen of the Union to raise a complaint about fundamental rights against the directive in front of the European Court of Justice, although he is not directly affected by it. However if such complaints were already admissible before the expiration of the time limit for transposition, the ECJ could use them to restrict the discretion of transposition of the Member States. To prevent this, one would have to stipulate that the complaint about fundamental rights before the ECJ was only admissible after the expiration of the time limit for transposition. The same principles could apply to the control of decisions of the European Community that are not directed at individuals but at Member States.

It becomes even more difficult when the Commission restricts itself to directing the application of the law of the Community by way of guidelines. It intends to do so regarding the prohibition against cartels $^{60}$. In German law it is without doubt that protection against such internal administrative guidelines is not provided for ${ }^{61}$. Legal protection would only exist against its application in individual cases. In the relationship between the Community and the Member States this would lead to the same gaps in protection that we have just worked out for the directives though. Only the procedural overcoming of the problem is more difficult because the guidelines are not binding neither in relation to the citizens nor in relation to the Member States. Nevertheless, in this case as well, the better solution seems to be the admissibility of the complaint about fundamental rights before the ECJ against guidelines, because only the guidelines can be ascribed to the Community, not the individual cartel decisions in the Member States.

The concept of attribution also enables delimitation of a further constellation. Regarding questions of detail, regulations and directives of the Community sometimes refer to the law of the Member States. To the extent that they do, the Community has not taken responsibility for the contents of the national regulations. Thus they can only be measured against the fundamental rights of the Member States.

\section{Interference}

In German constitutional law there are increasingly complicated reflections about the concept of an interference with a fundamental right ${ }^{62}$. The Strasbourg Court of Human Rights could not quite resist the urge either ${ }^{63}$. For example, they deny interference with the freedom of expression, when

60 White Book about the modernisation of regulations for the application of articles 85 and 86 ECC of 28.04.1999; critically in a special expertise German Monopolkommission: Kartellpolitische Wende in der Europäischen Union <http://www.monopolkommission.de/sg_28/text_htm>; Mestmäcker, Versuch einer kartellpolitischen Wende in der EU' (1999) Europäische Zeitschrift für Wirtschaftsrecht 523; Möschel, 'Systemwechsel im europäischen Wettbewerbsrecht?' (2000) Juristenzeitung 61.

$61 \quad$ BVerwGE 71, 342.

62 See only Bethge. 'Der Grundrechtseingriff', (1998) 57 Veröffentlichungen der Vereinigung der Deutschen Staatsrechtslehrer 7.

63 Details in C. Engel, Privater Rundfunk vor der Europäischen Menschenrechtskonvention (Law and Economics of International Telecommunications 19) (Baden-Baden, 1993) p. 444-446. 
the publisher could also achieve the same publicational impact in another way that is not undue ${ }^{64}$. In its core the dogmatic concept of an interference with a fundamental right serves the state and particularly the legislature by providing it with some room for discretion within the substantiate field of application of a fundamental right that is not controlled by the principle of proportionality. This is already a problematic task in constitutional law. It is inappropriate for a legislature that, like the European, only has a poor democratic legitimation.

\section{Formal limitations}

The complex system of formal limitations to fundamental rights developed by the Strasbourg Court need not be reported here in full ${ }^{65}$. But there is one element hat deserves our attention. The organs of Strasbourg derive from the formula "as prescribed by law" that the national institutions may not obviously have applied the applicable national law incorrectly ${ }^{66}$. The organs of Strasbourg are actually rather restrained in this respect ${ }^{67}$. By means of this restraint the Strasbourg Court prevents the danger that it is turned into an additional appellate court for all legal orders of the Member States. The Bundesverfassungsgericht interprets the respective limitations to the fundamental rights even more strictly. This becomes especially apparent when taking a look at the jurisdiction deriving from the application of Article 2 I Basic Law as a general right to freedom ${ }^{68}$. Such a general right inevitably has wide substantial limitations. Its practical impact thus consists mainly in subjectivising violations of objective constitutional rights, thus making the complaint about infringement of the constitution accessible.

This decision is already sound regarding the German Constitution. It is even better justified concerning the law of the Community. Since the Community legislature is so poorly legitimated, there is no reason to be careful with it. Quite the opposite: the Community is strengthened as a legal community and gains additional legitimacy when the citizens can also bring action before the Court of Justice against excesses of authority. This way the formal limitations of the fundamental rights become the dogmatic instrument to transform the principle of jurisdiction limited to specific issues and the principle of subsidiarity into standards against which individuals can have the European Court of Justice check Community acts affecting them.

\section{Material limitations}

The Charter establishes a complex system of substantial limitations to the fundamental rights. Firstly, by virtue of Article $52 \mathrm{I}$, the essence of all freedoms is brought under absolute protection. Furthermore, under the same article, any limitation must be in line with the principle of proportionality. The provision defines proportionality as asking that limitations be "necessary and genuinely meet objectives of general interest recognized by the Union or the need to protect the rights and freedoms of others". Article 52 III further declares the limitations of the parallel rights of

\footnotetext{
64 ECommHR ZE 2795/66, YECHR 12, 192, 194; ECommHR ZE 4517/70, YECHR 14, 548, 566 f.; ECommHR ZE 4570/70, Digest III, 423 f.; ECommHR B 5178/71, DR 8, 5, 13 f., \$S 85 ff.

65 Summary in: Engel Privater Rundfunk (note 63) 439-465.

66 Leading case ECtHR 26.04.1979, Ser. A 30, 1, 31, \ 49 - Sunday Times.

67 Details in: Engel Privater Rundfunk (note 63) 271 f.; but see also ECtHR 22.04.1992, Ser. A 226-B, SS 57-64 Rieme.

68 Substantially: BVerfGE 80, 137 - Reiten im Walde.
} 
the European Convention of Human Rights applicable ${ }^{69}$. Furthermore, Article 53 states that no regulation of the Charter may be interpreted as restricting the protection that international conventions provide for.

When deciding which aims are legitimate, the particularities of fundamental rights in a system of multilevel governance have to be taken into account. The mere will to harmonise is not sufficient for justification ${ }^{70}$ because this would constitute a hollow aim. Any possible European intervention leads to a level playing field for European citizens. It is even less sufficient that a compromise in the Council or in the Parliament could only be achieved by log-rolling ${ }^{71}$. The fundamental rights shall, in fact, constitute a form of protection from the hazard that its holders, during the political process, fall into bad ways. The problem goes even further though. In the normative economic discussion, systems competition between the Member States is no longer regarded as indubitably detrimental ${ }^{72}$. A fundamental rights Charter turns this question into a legal one. In future, competition between institutions will have to be discussed in terms of fundamental rights.

Protection of fundamental rights is a question of degree and standard. When the courts go too far, legislation and the administration can only operate within strict limits. Once more though, this finding is less important qua the European legislature than it is regarding the national legislatures. Since the European authorities only very poorly democratically legitimated, the protection offered by the fundamental rights has to be defined more strictly ${ }^{73}$. The Strasbourg Court of Justice has developed an elegant dogmatic instrument for this task: the margin of appreciation. An earlier version of the draft Charter even literally used the words from which the Strasbourg Court had developed this jurisprudence "necessary in a democratic society" ${ }^{74}$.

The margin of appreciation can do even more. It is open for all topoi by which means the level of protection of a fundamental right can be differentiated. The organs of Strasbourg use this, for example, to grant less protection to commercial statements than to idealistic ones ${ }^{75}$. Conversely, the media is increasingly protected the more its democratic task of intermediary between state and society is impeded or at risk ${ }^{76}$.

69 „Insofar as this Charter contains rights which correspond to rights guaranteed by the Convention for the Protection of Human Rights and Fundamental Freedoms, the meaning and scope of those rights shall be the same as those laid down by said Convention. This provision shall not prevent Union law providing more extensive protection“.

70 B. Simma/J.H.H. Weiler/M. C. Zökler, Kompetenzen und Grundrechte. Beschränkungen der Tabakwerbung aus der Sicht des Europarechts (Schriften zum europäischen Recht 59) (Berlin, 1999) p.142.

71 Log-rolling is a major concern raised by public choice theory, see e.g. P. Bernholz/F. Breyer, Grundlagen der Politischen Ökonomie II Ökonomische Theorie der Politik (Tübingen ${ }^{3}$ 1994) p.72-79.

72 See only L. Gerken (ed.), Competition among Institutions (Houndmills, 1995); M. Müller, Systemwettbewerb, Harmonisierung und Wettbewerbsverzerrung. Europa zwischen einem Wettbewerb der Gesetzgeber und vollständiger Harmonisierung (Wirtschaftsrecht und Wirtschaftspolitik 136) (Baden-Baden, 2000).

73 Pauly (note 35) EuR 1998, 243/248 and passim.

74 Article H.2 II 2, Doc. 4235/00. On the jurisprudence of the European Court of Human Rights see Engel, 'Die Schranken der Schranken der Europäischen Menschenrechtskonvention. Das Merkmal „notwendig in einer demokratischen Gesellschaft“ in den Schrankenvorbehalten, das Diskriminierungsverbot, und die „Margin of Appreciation“" (1986) Österreichische Zeitschrift für Öffentliches Recht und Völkerrecht 261.

75 Further Nolte, 'Werbefreiheit und Europäische Menschenrechtskonvention (1999) 63 Rabels Zeitschrift 507, p.514 f..

76 Since ECtHR 07.12.1976, Ser. A 24, 1, 23, \49 - Handyside; further to this aspect in Engel Privater Rundfunk (note 63) 50; more reasons that the organs of Strasbourg use for the differentiation of the level of protection: ibid. 459-461. 
The concept of the margin of appreciation also allows one to differentiate the level of protection according to the respective cultural background and regulatory tradition ${ }^{77}$. This seems to be of only minor importance for the fundamental rights of the Community though, because they are not, in any event, supposed to be valid for the autonomous actions of the Member States. However, the national differentiation of the level of protection eases the justification of differences regarding the enforcement of the law of the Community by the Member States. So not even a European Charter of Fundamental Rights could force the Community to a rigorously uniform enforcement of its rights. Moreover the regional differentiation of the level of protection provides justification for the fact that the Community leaves some room for discretion regarding the transposition of a directive, or, in the case of its exclusive authority, expressly accords Members States some discretion.

Finally, the margin of appreciation can solve a last problem. Despite lip service in the decisions of the European Court of Justice, fundamental rights are practically of no importance regarding their function as a limit to the legislature of the Community. Therefore, a legally binding Charter of Fundamental Rights that is enforceable by the courts demands a substantial alteration of the behaviour and mentality of the organs of the Community. This will not happen overnight. In relation to the Member States of the Convention of Human Rights the Strasbourg Court has used the margin of appreciation as a means of increasing the standard of fundamental rights gradually rather than abruptly ${ }^{78}$. The European Court of Justice could do the same with respect to the Community legislator. This matter of concern is, of course, of minor degree in relation to the organs of the Community than in relation to the Member States of the Convention of Human Rights. Because of the poor democratic legitimisation of the European legislature this is fundamentally just a pragmatic problem. When the European legislature goes too far in applying the Charter of Fundamental Rights, it may invoke reluctance by the Member States, or even risk that the level of protection will decrease again in the next alteration of the Treaty.

\section{Duties to protect}

The German Bundesverfassungsgericht has continually drawn duties to protect from the fundamental rights ${ }^{79}$. The Strasbourg Court of Justice operates in the same way ${ }^{80}$. In particular it has used the right of respect for the private life of Art. 8 I ECHR for this reason ${ }^{81}$. Article 7 of the Charter contains a norm that follows Art. 8 I ECHR $^{82}$ tightly. It is likely that the European Court of Justice would as well derive a duty to protect from this provision, when the enforcement of European fundamental rights is assigned to $\mathrm{it}^{83}$. This is also likely since Article 52 I 2 of the Charter allows the limitation of any fundamental freedom "if they are necessary and genuinely meet [...] the need to protect the rights and freedoms of others".

Duties to protect are more difficult to integrate into a system of multilevel governance than rights of protection. First of all, the rules of attribution have to be respected here as well. If the fundamental

\footnotetext{
77 Details in: Engel (note 74) ÖZöRV 1986, 276 and passim.

78 Further in: Engel (note 74) ÖZöRV 1986, 276 and passim.

79 J. Dietlein, Die Lehre von den grundrechtlichen Schutzpflichten (Berlin, 1992).

80 Since ECtHR 09.10.1970, Ser. A 32, 17, \ 32 - Airey; see also Classen, 'Die Ableitung von Schutzpflichten des Gesetzgebers aus Freiheitsrechten. Ein Vergleich von deutschem und französischem Verfassungsrecht sowie der Europäischen Menschenrechtskonvention' (1987) 36 Jahrbuch des öffentliches Rechts der Gegenwart 29.

81 Leading case: ECtHR 26.03.1985, Ser. A 91, 1, § 23 - X and Y vs. Netherlands.

82 Doc. $4149 / 00$.

83 See critically: Eickmeier (note 3) DVB1. 1999, 1029.
} 
rights impose a duty to legislate, then this duty is to be fulfilled by the organs of the Community, not by the Member States. A duty to protect deriving from the law of the Community but addressing the Member States can only evolve when it is to be fulfilled by means of the very enforcement of the law of the Community. This could, particularly, be the case when the Community indeed substantially assigns the enforcement of its cartel law to the Member States ${ }^{84}$.

More important is a second peculiarity. It becomes clear when comparing the European Union with a federal state. Let us assume that the constitution of a federal republic contains fundamental rights that are valid for the state as a whole. When the constitutional court draws a duty to protect from these rights, this does not alter the federal distribution of competencies. If the matter is a matter for the legislation or the administration of the federal states, the federal states are, at the same time, the addressees of this duty to protect, not the federation.

Duties to protect may not alter the distribution of jurisdiction between the Community and the Member States either. But this sentence is of much greater importance in the Community than in a federal state. Within the Community, the distribution of jurisdiction not only decides who has to fulfil the duty to protect, but also if it is to be fulfilled at all. This is based on a peculiarity of fundamental rights in a system of multilevel governance. Not only does the Community legislature lack a monopoly, but likewise do the fundamental rights of the Community. In a system of multilevel governance, the complete protection of fundamental rights of the individual is composed of the fundamental rights of the Community and the fundamental rights of the national constitutions. Consequently, in one and the same case the protection is split up into two procedures. Complaints against the infringement of European fundamental rights go to the European Court of Justice. Complaints against the violation of national fundamental freedoms go to the national constitutional court.

In the end this may, therefore, lead to gaps of protection. They occur when the fundamental rights or the means of their enforcement in a Member State are on a lower or different level than in the Community. This leads to a last peculiarity. Actually between the Community and the Member States jurisdiction is distributed according to a different principle than the competencies between the Federation and the Länder in the German Basic Law. The German constitution distributes the competencies according to the substance matter being regulated. The competencies of the European Communities on the other hand are delineated functionally. The Community is the assigned holder of the competence when it is necessary to fulfil one of the aims of the EC-Treaty.

However, this idea may not be transferred to the duties to protect that derive from the fundamental right of the Community because these rights have to be universal. They have to help the citizen especially where the Community intents to interfere in fields of their life whose regulation is assigned to the national legislature. So even in their function as duties to protect the fundamental rights of the Community do not hiddenly give the Community extra jurisdiction. Rather, they restrict room for discretion where the EC- and EU-Treaties have left it open. To put it in other words: fundamental rights never lead to absolute duties to protect. The duty to protect is limited to situations where the Community has jurisdiction for other reasons, for example for the realisation of a uniform internal market. 


\section{B. Relation of European Fundamental Rights and Remaining Primary Law}

When the European Charter of Fundamental Rights is finally incorporated in the EC- or EU-Treaty, the dogmatic relation between the fundamental rights and the remaining primary law has to be clarified. This question concerns the substantive law on the one hand, and the procedural law on the other. We have already covered the two most important problems regarding the substantive law: fundamental rights do not enlarge the competencies of the Community. According to Article 52 I 2 of the Charter, the fundamental rights can be restricted for every "objectives of general interest recognized by the Union“. The other norms of the law of the Community would form part of these aims.

It remains the question of the relation between fundamental rights and fundamental freedoms, like freedom of goods or freedom of movement. According to the jurisdiction of the European Court of Justice the fundamental freedoms are directly applicable. Up to now they have been principally used by the citizens against trade restrictions of the Member States though. The literature has frequently demanded that the fundamental freedoms also constitute a standard for the secondary law of the Community $^{85}$. Occasionally the Court of Justice has shown that it is of the same opinion ${ }^{86}$. In this light the fundamental rights and the fundamental freedoms would not be contrary but would complement each other. Put more straight forwardly: in the future, the Community legislature would have to respect both restrictions. The same applies to the relation between the fundamental rights and the rules of competition that are equally applicable to government action ${ }^{87}$.

Procedural problems may occur if, solely for fundamental rights, an unrestricted European complaint concerning fundamental rights infringement is introduced. This is because when one of the formal fundamental rights restrictions is respect for the objective law of the Community, then, the complaint about an infringement of fundamental rights becomes an instrument to overcome restrictions regarding the legal protection of violations of fundamental freedoms and of other objective Community law. However, fundamental rights can only be used against authoritative acts of the Community. The described dogmatic roundabout thus does only lead to an expansion of the legal protection against the legislature of the Community and against the enforcement of Community law by the Member States. This does not however give way to a complaint before the ECJ on the grounds of violation of the fundamental freedoms by the autonomous actions of a Member State.

\section{Relation to Other Fundamental Rights Codes}

The European Charter of Fundamental Rights will not be isolated. Accordingly their relation to other fundamental rights codes has to be determined. The first question is in the hand of the European constitutional legislator. Fundamental rights have for a long time been part of the law of the Community. According to Article 6 II EC they are to be derived from the European Convention for Human Rights and from the common constitutional traditions of the Member States. It is

\footnotetext{
85 Programmatic: Mestmäcker, 'Auf dem Wege zu einer Ordnungspolitik für Europa', in Festschrift von der Groeben (Baden-Baden, 1987) 9.

86 ECJ Case 240/83 Altöl [1985] 531, R 9.

87 ECJ jurisprudence since ECJ Case 14/68 Walt Wilhelm [1969] ECR 1 - Walt Wilhelm.
} 
advisable to eliminate the provision once the European Charter of Fundamental Rights is incorporated into the EC- or the EU-Treaty lest the Community create a "lawyers paradise" concerning the fundamental rights.

We have emphasised several times that the Charter of Fundamental Rights will contain fundamental rights without monopoly. They are only valid for such authoritative actions that can be attributed to the Community. This is not a defect to be cured by a competence of the Community for human rights policy. Rather, this is the only way to guarantee the protection of fundamental rights, without shifting from supranationality to a European federal state. This is why it is not necessary to further investigate how the Charter of Fundamental Rights can stand up against the rival national regulations for fundamental rights or how it could intersperse common matters of concern with their collaboration $^{88}$. This is because the rights of the Community are only a standard of control for authoritative actions that can be attributed to the Community.

Nevertheless, there will be an area of overlapping between the European Charter of Fundamental Rights, the fundamental rights of the national constitutions and the European Convention for Human Rights. It contains two elements. When the Member States enforce the law of the Community or fulfil legislative orders of the law of the Community this is attributed to the Community within the demonstrated restrictions. In the meantime the Member States use their own authoritative power. Therefore these actions are also subject to the fundamental rights of the national constitutions and of the European Convention for Human Rights. The Bundesverfassungsgericht went one step further in the Maastricht decision. It also, even if only subsidiarily, claims the control of genuine European authoritative power against the standards of German fundamental rights ${ }^{89}$. Similarly, the European Court of Human Rights claims control for the opening of the rights of the Member States for the European authoritative power ${ }^{90}$.

As far as a single act is, according to this, subject to several fundamental rights regulations, the dogmatic relation between these regulations has to be clarified. To the extent that fundamental rights bilaterally grant protection from the state, this is not a difficult task. The standards of control can be doubled. The authoritative actions have to meet the criteria of all regulations of fundamental rights at the same time. The prohibition against cartels proves that such a double control can also function in practice. Art. 81 ECC and the bans of cartel in the national antitrust law have always been applied in juxtaposition ${ }^{91}$. Especially from the view of Community law this can lead to unwanted consequences though. Although they are in compliance with Community law, authoritative actions that are attributed to the Community can remain ineffective. The conflict becomes even terser when duties to protect are derived from the national fundamental rights regulations. In that case the same authority can be faced with contradictory requirements. However, for the reasons already mentioned, this will not often be the case because the duties to protect that derive from the national fundamental rights regulations are only applicable to authoritative actions that are attributed to the Community. As long as several fundamental rights codes are applicable in juxtaposition, the holders of the fundamental rights gain the chance of a battle of the forum. They can strategically attempt to shift the conflict to a forum whose fundamental rights appear to be more in their favour.

\footnotetext{
88 An overview about the possibilities can be found in Engel, 'The Internet and the Nation State', in: C. Engel/K. H. Keller (eds.), Understanding the Impact of Global Networks on Local Social, Political and Cultural Values (Law and Economics of International Telecommunications 42) (Baden-Baden, 2000) 201, p.245-258.

91 Details in: U. Immenga/E.-J. Mestmäcker, GWB Kommentar (München² 1992) Einleitung, R 32-58.
} 


\section{Open flanks}

Two flanks are still open. From a dogmatic point of view the law developing actions of the European Court of Justice are also an authoritative act of the Community. But how can one achieve the aim that the European Court of Justice restricts itself by means of the fundamental rights? Furthermore we have demonstrated that the European Fundamental Rights alter the opportunity structure between the Community and the Member States, between the Member States themselves, between the organs of the Community and in relation to the political actors. How can the fathers of the Charter of Fundamental Rights prevent the risk that this price for an effective protection of fundamental rights is too high?

These flanks can hardly be closed by the dogmatics of the European Fundamental Rights alone because it is the European Court of Justice, who traditionally defines itself as the motor of the integration, which is responsible for the application and development of these dogmatics.

The Charter has reacted to the problem of competencies by the already mentioned Article 51 II. It shall explicitly state that the Charter does not expand the powers of the Community. When the Charter is incorporated in the European Treaties, one could establish in the same way that the fundamental rights are also applicable to the law developing action of the European Court of Justice. The meaning of such clauses is not to be underestimated. It is true that its importance would be small, if the judicial policy would only be directed by interests. But judicial policy is also influenced by ideas ${ }^{92}$. The, from a dogmatic point of view, similarly ill founded principle of subsidiarity has actually altered the jurisdiction of the European Court of Justice.

Nevertheless it is sensible to give some additional thoughts to the protection of the open flanks. One can start with three different elements: the right of initiative, the competence for the application of the Charter of Fundamental Rights and the application of competing regulations of fundamental rights.

When the European Court of Justice acts as a motor for integration, it is, from a functional perspective, a politic and not a judicial organ. As political organ it is weak because it has to wait until a suitable case is assigned to it. The narrower the initiative is formed, the narrower are the chances for a legally political active Court of Justice. But a restrictive procedure for the protection of fundamental rights makes little sense. Fundamental rights without the entitlement to an individual complaint are not satisfactory and only give scarce additional legitimacy to the Community. Moreover the fact that a wide right to initiate can on the contrary have a restrictive effect becomes clear from another condition for the political actions of the European Court of Justice. It can only practice its political power in legal forms. It has to interpret a provision of Community law in a way that serves its political intentions, and it has to justify every decision lege artis, even when it does not contribute to its political purposes. Finally the standards that it applies in all its decisions have to be consistent. Complaints about an infringement of fundamental rights can therefore force the Court of Justice to restrict its own room of discretion for future political action by means of increasingly precise dogmatics.

However, as mentioned the European Court of Justice would be forced to develop an open or hidden procedure of admissibility, as soon as the citizens of the Community have accepted the complaint about an infringement of fundamental rights. This also enables it to single out such

$92 \quad$ See again $Y e e$ (note 47). 
complaints that would be too restrictive in the future. Therefore it is advisable to grant the right to raise an action claiming infringement of fundamental rights to the Member States as well, and to expand the jurisdiction of national courts to bring questions regarding fundamental rights.

A much more radical solution would be not to assign the European fundamental rights to the European Court of Justice but to a new constitutional court of the Community ${ }^{93}$. This court could then also be responsible for the control of decisions of the European Court of Justice according to the standard of the European Fundamental Rights. Since its single standard for decisions would be fundamental rights, it is probable that it would constitute a more constitutional rather than integrative instrument. It can be doubted, that all Member States would accept such an alteration of the European treaties, though. Dogmatically the fundamental rights would remain on the same level in the hierarchy of norms as the remaining primary right of the Community. But the divided branches of the judiciary would externally evoke the impression that the European Community places fundamental rights above the remaining primary law. The European Court of Justice and the constitutional court would be pushed in a competition that would, above all, be sparked off in the dovetailing of the fundamental rights with the remaining primary law.

A more restrictive disciplinating impact could also derive from the competition of interpreters about the just interpretation of the European Charter of Fundamental Rights. This is already hardly preventable because the law of the Community is generally enforced by the Member States. The addressee could bring the act of enforcement before a national court alleging that the enforced norm violates the fundamental rights of the Community. It is true, that according to the jurisdiction of the Court of Justice a national court itself may not declare the secondary law of the Community invalid, but it has to submit the question to the Court of Justice ${ }^{94}$. This would be the same regarding an alleged fundamental rights infringement. However this way, national courts gain at least an autonomous competence of examination.

If all goes wrong, the national constitutional courts and the European Court of Human Rights remain to constitute a rearguard in case it should become apparent, that the European Court of Justice does not take the fundamental rights seriously or misuses them for integration-political purposes. The Bundesverfassungsgericht could intervene according to the principles of the Maastrichtdecision $^{95}$. In the same way the Strasbourg Court of Human Rights could decide against a Member State because it has assigned authority to the European Community without providing for a sufficient protection of the Human Rights ${ }^{96}$.

\footnotetext{
93 The question has been raised by Gaja, ,New Instruments and Institutions ?’, in The EU and Human Rights (Alston, 1999) 798.

94 ECJ Case 314/85 Foto-Frost [1987] 4199, 4232 .

95 See again BVerfGE 89, 155.

96 See again ECtHR 18.02.1999, Case 24833/94, R 32 - Matthews.
} 